\title{
Emergency and Essential Surgical Care Capacity across Primary, Secondary, and Tertiary Institutions in Meghalaya, India: A Cross-sectional Study
}

\author{
${ }^{1}$ Bonnie Y Chien, ${ }^{2}$ Khumukcham I Singh, ${ }^{3}$ Laksmi S Hashimoto-Govindasamy, ${ }^{4}$ Meena N Cherian, ${ }^{5}$ Manish Mehrotra \\ ${ }^{6}$ Paul P Francis, ${ }^{7}$ Natela Menabde
}

\begin{abstract}
Aim: This study aims to evaluate surgical care systems across tertiary, secondary, and primary health institutions in the state of Meghalaya, India.

Materials and methods: The government of Meghalaya conducted the first comprehensive assessment of surgical capacity at three levels of care: Tertiary hospitals, community health centers $(\mathrm{CHCs})$, and primary health centers (PHCs).

This cross-sectional survey utilized World Health Organization (WHO) tool for situational analysis to assess emergency and essential surgical care (EESC) to capture health facilities' capacity to perform life-saving and disabilitypreventing surgical interventions, such as resuscitation, surgical, trauma, obstetric, and anesthetic care. Data were collected across four categories: Infrastructure, human resources, surgical procedures, and equipment.
\end{abstract}

Results: The 55 facilities surveyed comprised 8 tertiary hospitals, $26 \mathrm{CHCs}$, and 21 PHCs. A total of 107,962 surgical presentations were reported across all facilities per year, with the greatest number presenting to PHC. No specialist doctors worked at $\mathrm{PHC}$ level; there were 1 anesthesiologist and 2 obstetricians at the $\mathrm{CHC}$ level. All of the PHCs or CHCs referred do not provide key emergency and essential surgical procedures, including resuscitation, cesarean section, general anesthesia, laparotomy, and closed and open treatment of fractures. At the tertiary level, only $50 \%$ provide cesarean section and laparotomy procedures.

Conclusion: The results of this WHO state survey demonstrate significant gaps, notably in resuscitation, at all lower level health

${ }^{1}$ Resident Physician, ${ }^{2}$ Member and Secretary, ${ }^{3}$ Associate Conjoint Lecturer, ${ }^{4}$ Lead, ${ }^{5}$ Member, ${ }^{6}$ Team Lead, ${ }^{7}$ Representative

${ }^{1}$ Department of Orthopaedic Surgery, Harvard Medical School Boston, Massachusetts, USA

${ }^{2}$ Government of Meghalaya Technical Working Group for EESC, Rajiv Ghandi Indian Institute of Management, Shillong Meghalaya, India

${ }^{3}$ Prince of Wales Hospital, The University of New South Wales Sydney, New South Wales, Australia

${ }^{4}$ Emergency and Essential Surgical Care Program, Department of Health Services and Delivery, World Health Organization Geneva, Switzerland

${ }^{5}$ WHO Global Initiative for Emergency and Essential Surgical Care (GIEESC) Program, VPS HealthCare, Abu Dhabi, United Arab Emirates

${ }^{6,7}$ WHO Country Office for India, WHO, New Delhi, India

Corresponding Author: Bonnie Y Chien, Resident Physician Department of Orthopaedic Surgery, Harvard Medical School Boston, Massachusetts, USA, Phone: +16507148048 , e-mail: mannil10@gmail.com facilities and the absence of obstetric procedures at some tertiary hospitals, in essential and emergency surgical capacity, including human resources, equipment, and infrastructure, across all levels of health institutions in Meghalaya.

Clinical significance: This study is an effort to identify the strengths and limitations of surgical capacity in the state of Meghalaya. The method of the study are simple and results can be extrapolated to other states of the country or any third world state which can translate into enhancement and redirection of resources for an optimum outcome.

\section{Strengths of the study}

- This study is driven by the motivation of the government of Meghalaya to address the issue of surgical care capacity.

- The study identifies concrete areas of need in surgical care capacity in a collaborative effort with the government of Meghalaya.

- Given the wealth of information on different levels of care centers provided by the government, specific recommendations for improvement can be made.

\section{Limitations of the study}

- Although detailed, the situation analysis survey tool is not fully comprehensive and cannot be used exclusively for program planning.

- Not all care centers were able to be surveyed; thus, the results may be representative of only those surveyed.

Keywords: India, Meghalaya, Surgical capacity, World Health Organization study.

How to cite this article: Chien BY, Singh KI, HashimotoGovindasamy LS, Cherian MN, Mehrotra M, Francis PP, Menabde N. Emergency and Essential Surgical Care Capacity across Primary, Secondary, and Tertiary Institutions in Meghalaya, India: A Cross-sectional Study. Int J Res Foundation Hospc Health Adm 2016;4(1):35-44.

\section{Source of support: Nil}

Conflict of interest: The authors include WHO staff. The views expressed in this publication reflect their views and not necessarily that of $\mathrm{WHO}$.

\section{INTRODUCTION}

Essential surgical care has the potential to address an estimated $11 \%$ of the global burden of disease. ${ }^{1}$ Surgical services at the first-referral level are an essential component of comprehensive health care and achieving universal coverage of health services. However, global public initiatives and in-country ministries of health have yet to prioritize surgical care systems, which encompass emergency medicine and surgery, anesthesia, trauma, 
and obstetrics and gynecology, in national health plans. ${ }^{2}$ Poor access to timely surgical services, particularly in rural regions of low- and middle-income countries, contributes to unnecessary morbidity and mortality from various treatable surgical conditions, including injuries, pregnancy complications, congenital anomalies, infections, and acute abdominal cases. ${ }^{3}$

Meghalaya is a state in northeast India, bound by the state of Assam in the north and Bangladesh to the west and south (Map 1). Its geography is marked by rugged and mountainous terrain that has impeded health service extension to remote villages across the seven districts. ${ }^{4}$ According to the 2011 census, the state population was approximately 2.96 million, of whom a majority, an estimated 2.37 million, live in rural areas. ${ }^{5}$ Meghalaya's health structure comprises district and civil hospitals at the tertiary level of care, community health centers (CHCs) at the secondary level, and primary health centers (PHCs) at the primary level. As of 2010, there were 11 functional hospitals, 28 functional CHCs, and 108 functional PHCs. ${ }^{6}$ Primary health centers are intended as the "cornerstone" of rural health service delivery, designed to be the first point of access to qualified doctors and as referral centers to both $\mathrm{CHCs}$ and tertiary hospitals. ${ }^{6}$ Community health centers are designed to provide a referral to tertiary hospitals, as well as specialist health care to the rural population. District or civil hospitals are providers of specialist tertiary services, including curative and preventative health care. Meghalaya faces significant health workforce shortages, with approximately 2.5 allopathic doctors per 10,000 people, compared with national estimates of
13.3 and 3.8 per 10,000, in urban and rural areas respectively. The 25.4 per 10,000 benchmarks were established by the World Health Organization (WHO). ${ }^{6,7}$

The Department of Health and Family Welfare, government of Meghalaya, has been following an action plan to promote essential and emergency surgical care (EESC). In 2011, it established a technical working group on EESC in order to strengthen surgical care systems. A top-down gap assessment was identified as the first step in formulating an evidence-based response to surgical care system needs. To date, there have been no comprehensive studies performed to assess the surgical capacity and needs of health facilities in Meghalaya.

\section{MATERIALS AND METHODS}

This is the first study of its kind, undertaken by the government of Meghalaya in collaboration with the WHO, in utilizing the WHO Situational Analysis Tool (SAT) across primary, secondary, and tertiary institutions (Map 1). The SAT was developed as a comprehensive questionnaire with which to quantify a facility's surgical capacity across four categories: Infrastructure, human resources, surgical procedures, and equipment. ${ }^{8} \mathrm{~A}$ total of 110 data points queried the availability of 8 types of health care personnel, 35 surgical procedures, and 67 items of equipment.

This survey was administered to 8 tertiary and all secondary health facilities and a sample of 21 of the 108 functional PHCs (Table 1). Of the 11 tertiary institutions in Meghalaya, three were excluded from the study because their mission does not include surgical services or they are not under the jurisdiction of the state; one

\section{HEALTH MAP OF MEGHALAYA NOT TO SCALE}
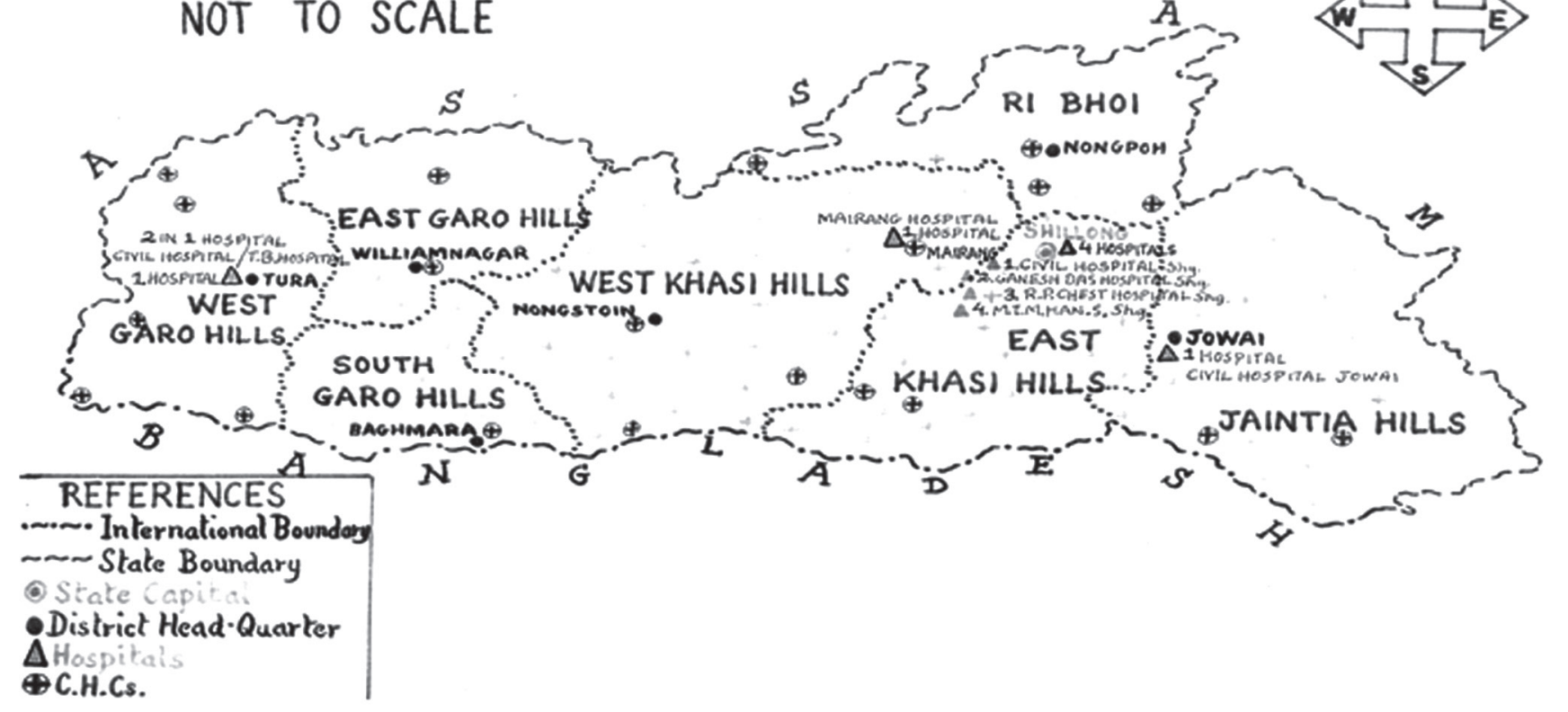

- District Head-Quarter (9).H.Cs.

Map 1: Health map of Meghalaya 
Table 1: Primary health centers, community health centers, and tertiary hospitals by district that completed the WHO SAT in the state of Meghalaya, India

\begin{tabular}{|c|c|c|}
\hline District & PHCs & $\mathrm{CHCs}$ \\
\hline \multirow[t]{6}{*}{ West Garo Hills } & PHC Bhaitbari & Ampati $\mathrm{CHC}$ \\
\hline & PHC Jeldupara & Phulbari $\mathrm{CHC}$ \\
\hline & PHC Kherapara & Dadinggre $\mathrm{CHC}$ \\
\hline & & Dalu CHC \\
\hline & & Mahendraganj $\mathrm{CHC}$ \\
\hline & & Selsella $\mathrm{CHC}$ \\
\hline \multirow[t]{3}{*}{ East Garo Hills } & PHC Sualamari & Resubelpara CHC \\
\hline & PHC Dainadubi & Rongjeng $\mathrm{CHC}$ \\
\hline & PHC Kharkutta & \\
\hline \multirow[t]{3}{*}{ South Garo Hills } & PHC Sibbari & Baghmara $\mathrm{CHC}$ \\
\hline & PHC Chokpot & \\
\hline & PHC Moheshkola & \\
\hline \multirow[t]{5}{*}{ East Khasi Hills } & PHC Laitlyngkot & Sohra CHC \\
\hline & PHC Shella & Ishamati $\mathrm{CHC}$ \\
\hline & PHC Smit & Pynursla CHC \\
\hline & & Mawiong $\mathrm{CHC}$ \\
\hline & & Mawsynram $\mathrm{CHC}$ \\
\hline \multirow[t]{4}{*}{ West Khasi Hills } & PHC Kynshi & Riangdo $\mathrm{CHC}$ \\
\hline & PHC Markasa & Mawkyrwat $\mathrm{CHC}$ \\
\hline & PHC Rambrai & Ranikor $\mathrm{CHC}$ \\
\hline & & Nongkhlaw $\mathrm{CHC}$ \\
\hline \multirow[t]{5}{*}{ Jaintia } & PHC Wapung & Khliehriat CHC \\
\hline & PHC Barato & Ummulong $\mathrm{CHC}$ \\
\hline & PHC Mynso & Nongtalang $\mathrm{CHC}$ \\
\hline & & Sutnga $\mathrm{CHC}$ \\
\hline & & Laskein $\mathrm{CHC}$ \\
\hline \multirow[t]{3}{*}{ Ri Bhoi } & PHC Kyrdem & Umsning $\mathrm{CHC}$ \\
\hline & PHC Mawhati & Patharkhmah $\mathrm{CHC}$ \\
\hline & $\begin{array}{l}\text { PHC Mawlasnai } \\
n=21\end{array}$ & $\begin{array}{l}\text { Bhoi Rymbong } \mathrm{CHC} \\
\mathrm{n}=26\end{array}$ \\
\hline
\end{tabular}

PHC: Primary health centers; $\mathrm{CHC}$ : Community health centers

is a psychiatric institution, the second is a dedicated tuberculosis hospital, and the third is a private mission hospital. Based on the in-country expertise of the technical working group, three PHCs were chosen from each of the seven districts to provide an overview of their surgical capacity and activities.

The WHO SAT was administered by the members of the government's technical working group to each of the health facilities and the survey was completed either by the member of the working group (KI Singh) with the health provider in charge of the hospital or in some cases, survey forms were filled only by the health provider directly. Data collection took place between September 2011 and April 2012. Data were collated and analyzed through the WHO Global DataCol Database for Emergency and Essential Surgical Care.

Where data were reported as a range on the survey, the average of the range values was utilized. Where a figure was reported as greater than a single value (i.e., $>5,000)$, then the value itself $(5,000)$ was utilized. The number of hospitals reporting positively for performing or
Table 2: Demographic data across the three levels of health institutions

\begin{tabular}{|c|c|c|}
\hline Facility type & PHCs $(n=21)$ & CHCs $(n=26)$ \\
\hline $\begin{array}{l}\text { Average population served } \\
\text { (range) }\end{array}$ & $\begin{array}{l}27,770 \\
(8,000-150,000)\end{array}$ & $\begin{array}{l}30,437 \\
(9,700-61,550)\end{array}$ \\
\hline $\begin{array}{l}\text { Average number of beds } \\
\text { (range) }\end{array}$ & $8(5-50)$ & $32(11-50)$ \\
\hline $\begin{array}{l}\text { Total number of function- } \\
\text { ing operating rooms (major } \\
\text { and minor) across all } \\
\text { facilities }\end{array}$ & 9 & 29 \\
\hline $\begin{array}{l}\text { Average total admissions } \\
\text { in } 1 \text { year (range) }\end{array}$ & $\begin{array}{l}428 \\
(0 \text { to }>5,000)\end{array}$ & $\begin{array}{l}1,875 \\
(101 \text { to }>5,000)\end{array}$ \\
\hline $\begin{array}{l}\text { Average number of pa- } \\
\text { tients requiring minor and } \\
\text { major surgical (including } \\
\text { Gyn/Obs) procedures per } \\
\text { year (range) }\end{array}$ & $\begin{array}{l}3,474 \\
(21 \text { to }>5,000)\end{array}$ & $\begin{array}{l}700 \\
(11 \text { to } 5,000)\end{array}$ \\
\hline $\begin{array}{l}\text { Average number of chil- } \\
\text { dren }(<15 \text { years) requiring } \\
\text { surgical procedures per } \\
\text { year }\end{array}$ & $\begin{array}{l}2,195 \\
(10 \text { to }>5,000)\end{array}$ & $\begin{array}{l}538 \\
(5 \text { to }>5,000)\end{array}$ \\
\hline $\begin{array}{l}\text { Average number of patients } \\
\text { referred for surgical inter- } \\
\text { vention to a higher level } \\
\text { facility per year (range) }\end{array}$ & $\begin{array}{l}1,580 \\
(21 \text { to }>5,000)\end{array}$ & $\begin{array}{l}476 \\
(10 \text { to } 5,000)\end{array}$ \\
\hline $\begin{array}{l}\text { Weighted mean of distance } \\
(\mathrm{km}) \text { to health facility }\end{array}$ & 42 & 53 \\
\hline
\end{tabular}

referring the procedure was divided by the total number of hospitals to determine the percentage. To determine the availability of equipment and supplies, the number of hospitals that had consistent, intermittent, or no access to a particular item of equipment was divided by the total number of hospitals. In order to better reflect the distances traveled by the average patient, the distance traveled prior to admission was expressed as a weighted mean. This was calculated by summing the products of annual admissions and average distance traveled for each facility, and then dividing by the sum of annual admissions for all facilities.

\section{RESULTS}

The WHO SAT was completed by 55 facilities across all 7 districts of Meghalaya, which comprised 8 tertiary facilities, 26 of the 28 functional CHCs, and 21 PHCs (Table 1).

The demographic details of the populations served by these facilities are expressed in Table 2. Of particular note is the high number of surgical patients presenting to PHCs, at an average of 3,474 per year. Per year, a total of 107,962 of patients across all levels of care for surgical procedures were children ( $<15$ years of age), comprising $67 \%$ of total surgical presentations. However, the range was large, some facilities handled 5 to 10 pediatric cases, while others handled more than 5,000 per year.

A total of 1,107 health workers were employed across the 55 facilities, the majority of whom $(78 \%)$ were 
Table 3: Total personnel across the three different types of health facilities

\begin{tabular}{lll}
\hline Facility type & $P H C s(n=21)$ & $\mathrm{CHCs}(n=26)$ \\
\hline $\begin{array}{l}\text { Surgeons (qualified) } \\
\begin{array}{l}\text { Anesthesiologist physicians } \\
\text { (qualified) }\end{array}\end{array}$ & 0 & 0 \\
$\begin{array}{l}\text { Obstetricians/gynecologists } \\
\text { (qualified) }\end{array}$ & 0 & 1 \\
$\begin{array}{l}\text { General doctors providing } \\
\text { surgery }\end{array}$ & 29 & 2 \\
$\begin{array}{l}\text { General doctors providing } \\
\text { anesthesia }\end{array}$ & 0 & 88 \\
$\begin{array}{l}\text { Nurse/clinical/assistant medical } \\
\text { officers providing anesthesia }\end{array}$ & 0 & 0 \\
$\begin{array}{l}\text { Clinical/assistant medical } \\
\text { officers providing surgery }\end{array}$ & 0 & 0 \\
Paramedics/midwives & 109 & 0 \\
\hline
\end{tabular}

paramedics or midwives (Table 3). A total of 193 general doctors provided surgery across all facilities, and every facility had at least one such full-time general doctor. Primary health centers did not have any specialists (qualified surgeons, anesthesiologists, or obstetricians/ gynecologists). There was only one anesthesiologist and two obstetricians in the $26 \mathrm{CHCs}$. At the tertiary level, 44 specialist medical staff were reported, but the majority of the medical workforce still comprised general doctors. Across all facilities, anesthesia was performed by qualified anesthesiologists, consistent with the provision context in India. ${ }^{9}$ As such, only one CHC with an anesthesiologist reported providing any form of anesthesia (Ketamine intravenous [IV] anesthesia), while all other $\mathrm{CHCs}$ referred. Table 4 presents the percentages at which PHCs, CHCs, and tertiary facilities provide and refer surgical procedures.

Of the 35 essential surgical interventions listed on the survey, 8 were performed at the PHC level; over $85 \%$ of PHCs provided care for acute burn management, incision and drainage of abscess, suturing, airway foreign body removal, resuscitation, and wound debridement; 9.5\% of PHCs could provide male circumcision, and 33.3\% could perform dilatation and curettage. Remarkably, over $90 \%$ of PHCs referred for all procedures, including resuscitation. Referrals were due to either lack of skills or lack of drugs or supplies. No PHCs referred due to nonfunctional equipment.

There was little difference between the procedures reported at $\mathrm{CHCs}$ and PHCs; the vast majority of $\mathrm{CHCs}$ provided only the same eight procedures. A further four procedures were provided at varying numbers of $\mathrm{CHCs}$. These were tubal ligation/vasectomy $(7.7 \%)$, ketamine IV anesthesia (3.8\%), management of closed fractures $(38.5 \%)$, and joint dislocation reduction (7.7\%). However, with the exception of two procedures, management of abscess and dilatation and curettage, over $92 \%$ of $\mathrm{CHCs}$ referred for all procedures. Over $85 \%$ of CHCs made referrals due to lack of skills, up to $15 \%$ due to nonfunctional equipment, and up to $12 \%$ due to lack of drugs and supplies.

All the PHCs and CHCs referred for resuscitation, cesarean section, laparotomy, general anesthesia, and closed treatment of fractures.

All tertiary hospitals provided resuscitation, and $75 \%$ provided all four anesthetic procedures (general inhalational anesthesia, ketamine IV anesthesia, and regional and spinal anesthesia). Only $50 \%$ of the tertiary hospitals performed cesarean sections, laparotomy, chest tube insertion, or cricothyroidotomy, while less than $40 \%$ provided general surgical procedures (including appendectomy, hernia repair, and hydrocelectomy) or pediatric procedures (including neonatal surgery, cleft lift, and club foot repair).

Even at the tertiary level, the majority of procedures, even in the instances where they were reported as provided, were still referred, with the exception of procedures that could also be provided at the PHC level (incision and drainage of abscess, suturing, anesthetic procedures, wound debridement, and dilatation and curettage). In particular, 37\% of tertiary hospitals reported referring for resuscitation. Among the different reasons for referral, lack of skills constituted the primary reason for referral for the majority of procedures. None of the hospitals provided cataract repair.

The availability and consistency of access to infrastructure are depicted in Table 5 . Notably, $75 \%$ of tertiary hospitals, $96 \%$ of CHCs, and $100 \%$ of PHCs reported no access to a blood bank.

A third of PHCs did not have access to an oxygen source and 52\% reported having no access to running water or resuscitation equipment. No surgical, anesthetic, or pain management guidelines were reported, though $67 \%$ had access to emergency guidelines.

More than $92 \%$ of $\mathrm{CHC}$ reported no access to emergency, anesthesia, surgery, or pain management guidelines. A total of $96 \%$ had no anesthesia machine, $85 \%$ had no postoperative room.

Even at the tertiary level, access to guidelines was poor; $63 \%$ reported no access to emergency and $75 \%$ reported no access to surgical guidelines. All tertiary institutions had full access to electricity, running water, and medical records; and $88 \%$ reported the constant availability of oxygen.

All facilities had at least intermittent access to face masks, but all PHCs and 54\% of CHCs had no access to eye protection. 
Table 4: Procedures offered, referral for procedures, and reasons for referral at PHCs, CHCs, and tertiary facilities

\begin{tabular}{|c|c|c|c|c|}
\hline $\begin{array}{l}\text { Key } \\
\text { PHCs }(n=21) \\
\text { CHCs }(n=26) \\
\text { Tertiary }(n=8)\end{array}$ & $\begin{array}{l}\text { Percent } \\
\text { that provide } \\
\text { procedure }\end{array}$ & $\begin{array}{l}\text { Percent } \\
\text { that refer }\end{array}$ & $\begin{array}{l}\text { Percent that } \\
\text { refer due to lack } \\
\text { of skills/license }\end{array}$ & $\begin{array}{l}\text { Percent that refer } \\
\text { due to nonfunctional } \\
\text { equipment }\end{array}$ \\
\hline \multicolumn{5}{|l|}{ Anesthesiology and airway management } \\
\hline \multirow{3}{*}{$\begin{array}{l}\text { Resuscitation (airway, hemorrhage, peripheral percutaneous } \\
\text { intravenous access, peripheral venous cutdown) }\end{array}$} & 95.2 & 100.0 & 9.5 & 0 \\
\hline & 92.3 & 100.0 & 92.3 & 15.4 \\
\hline & 100.0 & 37.5 & 25.0 & 25.0 \\
\hline \multirow[t]{3}{*}{ Removal of foreign body (throat/eye/ear/nose) } & 100.0 & 100.0 & 95.2 & 0 \\
\hline & 100.0 & 100.0 & 92.3 & 19.2 \\
\hline & 100.0 & 50.0 & 50.0 & 0 \\
\hline \multirow[t]{3}{*}{ Cricothyroidotomy/tracheostomy } & 0 & 100.0 & 95.2 & 0 \\
\hline & 0 & 100.0 & 96.2 & 3.8 \\
\hline & 50.0 & 62.5 & 50.0 & 37.5 \\
\hline \multirow[t]{3}{*}{ General anesthesia inhalational } & 0 & 90.5 & 95.2 & 0 \\
\hline & 0 & 100.0 & 96.2 & 3.8 \\
\hline & 75.0 & 37.5 & 25.0 & 12.5 \\
\hline \multirow[t]{3}{*}{ Ketamine IV anesthesia } & 0 & 100.0 & 95.2 & 0 \\
\hline & 3.8 & 96.2 & 96.2 & 0 \\
\hline & 75.0 & 37.5 & 25.0 & 12.5 \\
\hline \multirow[t]{3}{*}{ Regional anesthesia blocks } & 0 & 100 & 95.2 & 0 \\
\hline & 0 & 100 & 100 & 3.8 \\
\hline & 75.0 & 37.5 & 25.0 & 12.5 \\
\hline \multirow[t]{3}{*}{ Spinal anesthesia } & 0 & 100 & 95.2 & 0 \\
\hline & 0 & 100.0 & 100.0 & 3.8 \\
\hline & 75.0 & 37.5 & 25.0 & 12.5 \\
\hline \multicolumn{5}{|l|}{ General and congenital } \\
\hline \multirow[t]{3}{*}{ Biopsy (lymph node, mass, other) } & 0 & 100.0 & 100.0 & 0 \\
\hline & 0 & 100.0 & 100.0 & 3.8 \\
\hline & 50.0 & 50.0 & 37.5 & 0 \\
\hline \multirow[t]{3}{*}{ Appendectomy } & 0 & 100.0 & 95.2 & 0 \\
\hline & 0 & 100.0 & 96.2 & 7.7 \\
\hline & 37.5 & 62.5 & 50.0 & 12.5 \\
\hline \multirow{3}{*}{$\begin{array}{l}\text { Laparotomy (uterine rupture, ectopic pregnancy, acute } \\
\text { abdomen, intestinal obstruction, perforation, injuries) }\end{array}$} & 0 & 100.0 & 95.2 & 0 \\
\hline & 0 & 100.0 & 96.2 & 7.7 \\
\hline & 50.0 & 75.0 & 50.0 & 12.5 \\
\hline \multirow{3}{*}{$\begin{array}{l}\text { Suturing (for wounds, episiotomy, critical, and vaginal } \\
\text { lacerations) }\end{array}$} & 90.5 & 100.0 & 100.0 & 0 \\
\hline & 96.2 & 92.3 & 69.2 & 11.5 \\
\hline & 87.5 & 37.5 & 12.5 & 12.5 \\
\hline \multirow[t]{3}{*}{ Incision and drainage of abscess } & 85.7 & 95.2 & 90.5 & 0 \\
\hline & 96.2 & 19.2 & 7.7 & 11.5 \\
\hline & 100.0 & 0 & 0 & 0 \\
\hline \multirow[t]{3}{*}{ Acute burn management } & 100.0 & 100.0 & 95.2 & 0 \\
\hline & 92.3 & 96.2 & 46.2 & 15.4 \\
\hline & 100.0 & 50.0 & 25.0 & 12.5 \\
\hline \multirow[t]{3}{*}{ Hernia repair (strangulated, elective) } & 0 & 100.0 & 95.2 & 0 \\
\hline & 0 & 100.0 & 96.2 & 7.7 \\
\hline & 37.5 & 62.5 & 50.0 & 12.5 \\
\hline \multirow[t]{3}{*}{ Hydrocele } & 0 & 100.0 & 95.2 & 0 \\
\hline & 0 & 100.0 & 96.2 & 7.7 \\
\hline & 37.5 & 62.5 & 50.0 & 12.5 \\
\hline \multirow[t]{3}{*}{ Cystostomy } & 0 & 100.0 & 95.2 & 0 \\
\hline & 0 & 100.0 & 96.2 & 7.7 \\
\hline & 37.5 & 62.5 & 50.0 & 12.5 \\
\hline
\end{tabular}




\begin{tabular}{|c|c|c|c|c|}
\hline $\begin{array}{l}\text { Key } \\
\text { PHCs }(n=21) \\
\text { CHCs }(n=26) \\
\text { Tertiary }(n=8)\end{array}$ & $\begin{array}{l}\text { Percent } \\
\text { that provide } \\
\text { procedure }\end{array}$ & $\begin{array}{l}\text { Percent } \\
\text { that refer }\end{array}$ & $\begin{array}{l}\text { Percent that } \\
\text { refer due to lack } \\
\text { of skills/license }\end{array}$ & $\begin{array}{l}\text { Percent that refer } \\
\text { due to nonfunctional } \\
\text { equipment }\end{array}$ \\
\hline \multirow[t]{3}{*}{ Cleft lip repair } & 0 & 100.0 & 95.2 & 0 \\
\hline & 0 & 100.0 & 100.0 & 0 \\
\hline & 12.5 & 87.5 & 87.5 & 0 \\
\hline \multirow[t]{3}{*}{ Congenital hernia repair } & 0 & 100.0 & 95.2 & 0 \\
\hline & 0 & 100.0 & 92.3 & 7.7 \\
\hline & 37.5 & 62.5 & 50.0 & 12.5 \\
\hline \multirow{3}{*}{$\begin{array}{l}\text { Neonatal surgery: Abdominal wall defect, colostomy } \\
\text { imperforate anus, intussusceptions }\end{array}$} & 0 & 100.0 & 95.2 & 0 \\
\hline & 0 & 100.0 & 92.3 & 7.7 \\
\hline & 37.5 & 62.5 & 50.0 & 12.5 \\
\hline \multirow[t]{3}{*}{ Cataract surgery } & 0 & 100.0 & 95.2 & 0 \\
\hline & 0 & 100.0 & 100.0 & 3.8 \\
\hline & 0 & 87.5 & 87.5 & 0 \\
\hline \multirow[t]{3}{*}{ Acute burn management } & 100.0 & 100.0 & 95.2 & 0 \\
\hline & 92.3 & 96.2 & 46.2 & 15.4 \\
\hline & 100.0 & 50.0 & 25.0 & 12.5 \\
\hline \multicolumn{5}{|l|}{ Reproductive health } \\
\hline \multirow[t]{3}{*}{ Cesarean section } & 0 & 100.0 & 100.0 & 0 \\
\hline & 0 & 100.0 & 84.6 & 15.4 \\
\hline & 50.0 & 50.0 & 50.0 & 0 \\
\hline \multirow[t]{3}{*}{ Dilatation and curettage } & 33.3 & 95.2 & 71.4 & 0 \\
\hline & 69.2 & 26.9 & 23.1 & 7.7 \\
\hline & 62.5 & 37.5 & 12.5 & 0 \\
\hline \multirow[t]{3}{*}{ Tubal ligation/vasectomy } & 4.8 & 100.0 & 95.2 & 0 \\
\hline & 7.7 & 100.0 & 96.2 & 3.8 \\
\hline & 75.0 & 75.0 & 75.0 & 0 \\
\hline \multirow[t]{3}{*}{ Obstetric fistula repair } & 0 & 100.0 & 100.0 & 0 \\
\hline & 0 & 100.0 & 88.5 & 7.7 \\
\hline & 50.0 & 50.0 & 50.0 & 12.5 \\
\hline \multirow[t]{3}{*}{ Male circumcision } & 9.5 & 90.5 & 85.7 & 0 \\
\hline & 0 & 100.0 & 92.3 & 7.7 \\
\hline & 37.5 & 62.5 & 50.0 & 12.5 \\
\hline \multicolumn{5}{|l|}{ Orthopedics and traumatology } \\
\hline \multirow[t]{3}{*}{ Chest tube insertion } & 0 & 100.0 & 95.2 & 0 \\
\hline & 0 & 100.0 & 96.2 & 3.8 \\
\hline & 50.0 & 50.0 & 50.0 & 25.0 \\
\hline \multirow[t]{3}{*}{ Closed treatment of fracture } & 0 & 100.0 & 95.2 & 0 \\
\hline & 38.5 & 100.0 & 100.0 & 3.8 \\
\hline & 87.5 & 62.5 & 62.5 & 0 \\
\hline \multirow[t]{3}{*}{ Open treatment of fracture } & 0 & 100.0 & 95.2 & 0 \\
\hline & 0 & 100.0 & 100.0 & 3.8 \\
\hline & 37.5 & 62.5 & 62.5 & 0 \\
\hline \multirow[t]{3}{*}{ Drainage of osteomyelitis/septic arthritis } & 0 & 100.0 & 95.2 & 0 \\
\hline & 0 & 100.0 & 100.0 & 3.8 \\
\hline & 50.0 & 62.5 & 50.0 & 0 \\
\hline \multirow[t]{3}{*}{ Limb amputation } & 0 & 100.0 & 95.2 & 0 \\
\hline & 0 & 100.0 & 100.0 & 3.8 \\
\hline & 37.5 & 62.5 & 62.5 & 0 \\
\hline \multirow[t]{3}{*}{ Wound debridement } & 85.7 & 100 & 95.2 & 0 \\
\hline & 100.0 & 92.3 & 7.7 & 11.5 \\
\hline & 100.0 & 12.5 & 0 & 0 \\
\hline \multirow[t]{3}{*}{ Clubfoot repair } & 0 & 100.0 & 95.2 & 0 \\
\hline & 0 & 100.0 & 100.0 & 3.8 \\
\hline & 37.5 & 62.5 & 62.5 & 0 \\
\hline
\end{tabular}


Table 5: Equipment and infrastructure at PHCs, CHCs, and tertiary hospitals

\begin{tabular}{|c|c|c|c|c|c|}
\hline $\begin{array}{l}\text { Key } \\
\text { PHCs }(n=21) \\
\text { CHCs }(n=26) \\
\text { Tertiary }(n=8)\end{array}$ & $\begin{array}{l}\text { Percent of } \\
\text { facilities with } \\
\text { consistent } \\
\text { access }\end{array}$ & $\begin{array}{l}\text { Percent of } \\
\text { facilities with } \\
\text { intermittent } \\
\text { access }\end{array}$ & $\begin{array}{l}\text { Key } \\
\text { PHCs }(n=21) \\
\text { CHCs }(n=26) \\
\text { Tertiary }(n=8)\end{array}$ & $\begin{array}{l}\text { Percent of } \\
\text { facilities with } \\
\text { consistent } \\
\text { access }\end{array}$ & $\begin{array}{l}\text { Percent of } \\
\text { facilities with } \\
\text { intermittent } \\
\text { access }\end{array}$ \\
\hline \multirow[t]{3}{*}{ Blood bank } & 0 & 0 & \multirow[t]{3}{*}{ Suture } & 95.2 & 4.8 \\
\hline & 3.8 & 0 & & 80.8 & 15.4 \\
\hline & 12.5 & 12.5 & & 100.0 & 0 \\
\hline \multirow[t]{3}{*}{ Electricity } & 76.2 & 23.8 & \multirow[t]{3}{*}{ Nasogastric tube } & 95.2 & 4.8 \\
\hline & 76.9 & 23.1 & & 61.5 & 26.9 \\
\hline & 100.0 & 0 & & 75.0 & 0 \\
\hline \multirow[t]{3}{*}{ Generator } & 28.6 & 42.9 & \multirow[t]{3}{*}{ Retractor } & 95.2 & 0 \\
\hline & 65.4 & 11.5 & & 80.8 & 15.4 \\
\hline & 87.5 & 0 & & 85.7 & 0 \\
\hline \multirow[t]{3}{*}{ Running water } & 28.6 & 19.0 & \multirow[t]{3}{*}{ Sterilizer } & 95.2 & 4.8 \\
\hline & 50.0 & 38.5 & & 80.8 & 19.2 \\
\hline & 100.0 & 0 & & 100.0 & 0 \\
\hline \multirow[t]{3}{*}{ Medical records } & 81.0 & 9.5 & \multirow[t]{3}{*}{ Sterile gauze dressing } & 95.2 & 4.8 \\
\hline & 96.2 & 3.8 & & 84.6 & 11.5 \\
\hline & 100.0 & 0 & & 100.0 & 0 \\
\hline \multirow[t]{3}{*}{ Surgical guidelines } & 0 & 0 & \multirow[t]{3}{*}{ Syringes } & 95.2 & 0 \\
\hline & 0 & 3.8 & & 92.3 & 7.7 \\
\hline & 25.0 & 0 & & 100.0 & 0 \\
\hline \multirow[t]{3}{*}{ Emergency guidelines } & 33.3 & 0 & \multirow[t]{3}{*}{ Anesthesia machine } & 0 & 0 \\
\hline & 3.8 & 3.8 & & 3.8 & 0 \\
\hline & 25.0 & 12.5 & & 75.0 & 0 \\
\hline \multirow[t]{3}{*}{ Pain management guidelines } & 0 & 0 & \multirow[t]{3}{*}{ Cricothyroidotomy set } & 0 & 0 \\
\hline & 3.8 & 3.8 & & 0 & 0 \\
\hline & 50.0 & 0 & & 37.5 & 12.5 \\
\hline \multirow[t]{3}{*}{ Anesthetic guidelines } & 0 & 0 & \multirow[t]{3}{*}{ IV cannula } & 95.2 & 4.8 \\
\hline & 3.8 & 0 & & 84.6 & 15.4 \\
\hline & 75.0 & 0 & & 100.0 & 0 \\
\hline \multirow[t]{3}{*}{ Emergency room } & 19.0 & 14.3 & \multirow[t]{3}{*}{ IV infusion set } & 95.2 & 4.8 \\
\hline & 65.4 & 23.1 & & 96.2 & 3.8 \\
\hline & 87.5 & 0 & & 100.0 & 0 \\
\hline Hemoglobin and urine analysis & 76.2 & 9.5 & IV infusor bags & 0 & 0 \\
\hline & 73.1 & 15.4 & & 26.9 & 11.5 \\
\hline & 100.0 & 0 & & 62.5 & 0 \\
\hline Face masks & 85.7 & 0 & Endotracheal tubes cuffed & 0 & 0 \\
\hline & 73.1 & 26.9 & & 11.5 & 38.5 \\
\hline & 100.0 & 0 & & 62.5 & 25.0 \\
\hline Eye protection & 0 & 0 & Endotracheal tubes uncuffed & 0 & 0 \\
\hline & 0 & 46.2 & & 15.4 & 34.6 \\
\hline & 37.5 & 25.0 & & 62.5 & 25.0 \\
\hline Forceps (artery) & 100.0 & 0 & Urinary catheter & 100.0 & 0 \\
\hline & 80.8 & 19.2 & & 73.1 & 23.1 \\
\hline & 100.0 & 0 & & 100.0 & 0 \\
\hline Gloves (sterile) & 100.0 & 0 & Blood pressure measuring & 100.0 & 0 \\
\hline & 88.5 & 11.5 & equipment & 96.2 & 3.8 \\
\hline & 100.0 & 0 & & 100.0 & 0 \\
\hline Gloves (nonsterile) & 100.0 & 0 & Laryngoscope (adult) & 0 & 28.6 \\
\hline & 88.5 & 11.5 & & 7.7 & 42.3 \\
\hline & 100.0 & 0 & & 62.5 & 25.0 \\
\hline Scalpel handle with blade & 100.0 & 0 & Laryngoscope (pediatric) & 0 & 19.0 \\
\hline & 84.6 & 15.4 & & 7.7 & 46.2 \\
\hline & 87.5 & 12.5 & & 62.5 & 25.0 \\
\hline
\end{tabular}

(Contd...) 


\begin{tabular}{|c|c|c|c|c|c|}
\hline $\begin{array}{l}\text { Key } \\
\text { PHCs }(n=21) \\
\text { CHCs }(n=26) \\
\text { Tertiary }(n=8)\end{array}$ & $\begin{array}{l}\text { Percent of } \\
\text { facilities with } \\
\text { consistent } \\
\text { access }\end{array}$ & $\begin{array}{l}\text { Percent of } \\
\text { facilities with } \\
\text { intermittent } \\
\text { access }\end{array}$ & $\begin{array}{l}\text { Key } \\
\text { PHCs }(n=21) \\
\text { CHCs }(n=26) \\
\text { Tertiary }(n=8)\end{array}$ & $\begin{array}{l}\text { Percent of } \\
\text { facilities with } \\
\text { consistent } \\
\text { access }\end{array}$ & $\begin{array}{l}\text { Percent of } \\
\text { facilities with } \\
\text { intermittent } \\
\text { access }\end{array}$ \\
\hline \multirow[t]{3}{*}{ Magill forceps (adult) } & 0 & 0 & \multirow[t]{3}{*}{ Scalp vein infusion set } & 95.2 & 4.8 \\
\hline & 0 & 34.6 & & 84.6 & 15.4 \\
\hline & 50.0 & 25.0 & & 100.0 & 0 \\
\hline \multirow[t]{3}{*}{ Magill forceps (pediatric) } & 0 & 0 & \multirow[t]{3}{*}{ Stethoscope } & 95.2 & 4.8 \\
\hline & 0 & 34.6 & & 100.0 & 0 \\
\hline & 50.0 & 25.0 & & 100.0 & 0 \\
\hline \multirow{3}{*}{$\begin{array}{l}\text { Mask and tubing to connect to } \\
\text { oxygen supply }\end{array}$} & 38.1 & 33.3 & \multirow[t]{3}{*}{ Radiography } & 0 & 0 \\
\hline & 73.1 & 11.5 & & 26.9 & 30.8 \\
\hline & 75.0 & 25.0 & & 100.0 & 0 \\
\hline \multirow[t]{3}{*}{ Oropharyngeal airway (adult) } & 95.2 & 0 & \multirow[t]{3}{*}{ Chest tube insertion equipment } & 0 & 0 \\
\hline & 53.8 & 30.8 & & 3.8 & 7.7 \\
\hline & 75.0 & 0 & & 50.0 & 0 \\
\hline \multirow[t]{3}{*}{ Oropharyngeal airway (pediatric) } & 95.2 & 0 & \multirow[t]{3}{*}{ Splints for arms, legs } & 100.0 & 0 \\
\hline & 46.2 & 38.5 & & 65.4 & 23.4 \\
\hline & 75.0 & 0 & & 87.5 & 12.5 \\
\hline \multirow[t]{3}{*}{ Oxygen concentrator } & 4.8 & 0 & \multirow[t]{3}{*}{ Tourniquet } & 95.2 & 0 \\
\hline & 11.5 & 23.1 & & 88.5 & 11.5 \\
\hline & 87.5 & 0 & & 87.5 & 12.5 \\
\hline \multirow[t]{3}{*}{ Oxygen cylinder } & 47.6 & 9.5 & \multirow[t]{3}{*}{ Vaginal speculum } & 95.2 & 4.8 \\
\hline & 65.4 & 23.6 & & 92.3 & 7.7 \\
\hline & 87.5 & 12.5 & & 100.0 & 0 \\
\hline \multirow[t]{3}{*}{ Postoperative recovery room } & 0 & 0 & \multirow[t]{3}{*}{ Suction catheter } & 95.2 & 0 \\
\hline & 7.7 & 7.7 & & 61.5 & 34.6 \\
\hline & 50.0 & 12.5 & & 75.0 & 25.0 \\
\hline \multirow{3}{*}{$\begin{array}{l}\text { Resuscitation bag, valve, and } \\
\text { mask (adult) }\end{array}$} & 9.5 & 38.1 & \multirow[t]{3}{*}{ Disposable needles } & 100.0 & 0 \\
\hline & 30.8 & 61.5 & & 76.9 & 15.4 \\
\hline & 62.5 & 37.5 & & 100.0 & 0 \\
\hline \multirow{3}{*}{$\begin{array}{l}\text { Resuscitation bag, valve, and } \\
\text { mask (pediatric) }\end{array}$} & 14.3 & 71.4 & \multirow[t]{3}{*}{ Light source } & 95.2 & 0 \\
\hline & 34.6 & 53.8 & & 84.6 & 11.5 \\
\hline & 50.0 & 50.0 & & 100.0 & 0 \\
\hline
\end{tabular}

\section{DISCUSSION}

This study demonstrated little difference between the surgical capacity of PHCs and CHCs, despite their different mandates. The large average number of surgical patients $(3,474)$ presenting to PHCs compared with other levels suggests that PHCs are serving their role as the first point of care for the rural population. However, the high number of referrals from PHCs (on average 1,580) and their inability to undertake surgical procedures due to lack of skills or resources is concerning. Although it is unrealistic to expect PHCs to undertake complex surgical procedures, given they are staffed by only one general doctor and no specialists, resuscitation and stabilization of surgical patients are vital to safe transfer for a referral to $\mathrm{CHC}$ or tertiary hospitals. To date, over $90 \%$ of PHCs referred for all surgical procedures including resuscitation. This is particularly important given the significant distances to tertiary referral hospitals (weighted mean distance $118 \mathrm{~km}$ ), difficult terrain, limited private vehicle ownership, and developing road infrastructure in Meghalaya. ${ }^{10}$ Thus, it is paramount to develop the capacity and self-sufficiency of the PHCs and first referral facilities, such as CHCs that are relatively more accessible for the rural population.

In spite of their role as referral centers, our results found that $\mathrm{CHCs}$ are minimally more developed than PHCs. Across the $26 \mathrm{CHCs}$ surveyed, there were no qualified surgeons, with only one anesthesiologist and two obstetricians/gynecologists. Nationally, only $10 \%$ of CHCs have anesthetists, and, according to Mavalankar and Siram," "adequate training is not included in the MBBS curriculum" and as such, "general doctors are unable to perform anaesthesia services, thereby increasing the number of referrals to specialists." Quality anesthetic care, including the capacity for resuscitation, are vital to effective emergency obstetric care and the management of life-threatening complications. ${ }^{11}$ This 
is compounded by the significant national shortage of obstetricians capable of performing comprehensive emergency obstetric care, including cesarean deliveries. ${ }^{12,13}$ Nationally, this contributes to the high maternal death ratio, with an estimated total of 117,000 maternal deaths per year. ${ }^{14}$ In Meghalaya, this specialized workforce shortage is bridged by general doctors providing surgery, but none of the CHCs and only $50 \%$ of tertiary hospitals provide cesarean section. It is crucial then to enhance the skills of general doctors at all health care levels to provide basic emergency surgical care. The WHO Primary Surgical Care Package defines these basic surgical procedures and those requiring advanced skills, which can be integrated into national and local plans to address in-country needs. ${ }^{8}$

The significant number of referrals made from tertiary hospitals, on average 888 per year, is of similar concern. Some tertiary hospitals did not have staff across all specializations and most have an overwhelmingly large patient pool, which includes patients referred from other facilities. In addition, different tertiary hospitals have different provision of specialized services. For instance, in Shillong, a city of over 200,000 people, the Civil Hospital does not provide maternal and child health care or cesarean section; such services are instead provided at the Ganesh Das Hospital. ${ }^{15}$ Tertiary facilities also refer out-of-state, with some expenses borne by the government.

Optimizing the capacity of general doctors, at both the PHC and CHC level, through training in basic surgical skills, and ensuring consistent access to guidelines (in emergency care, pain management, surgery, and anesthesia), equipment, and drugs has the potential to reduce the burden on higher level facilities and address workforce shortages without compromising the quality of care. However, particularly in terms of surgery and anesthesia, this demands ongoing provision of training, supervision, monitoring, and evaluation in order to ensure that adequate standards are maintained. ${ }^{16}$

Short-term training courses have been demonstrably effective in extending the capacity of general doctors. Medical officers can be effectively trained in basic emergency obstetric care. An emergency obstetrics training program performed in the Indian states of Gujarat and Rajasthan demonstrated that selecting trainees with some prior surgical training and who had access to equipped facilities were far more likely to be performing cesarean deliveries after training and to become more successful providers of comprehensive emergency obstetric care. ${ }^{13}$ Similarly, a two-day trauma course conducted at a teaching hospital in Banglore, India, involving general practitioners (GPs), local surgeons, and residents in training found that although GPs began with a significantly lower precourse test score than surgeons, their postcourse test score was just as high as the surgeons.'17 In Meghalaya, with a workforce skewed toward general doctors rather than surgeons at all levels of health facilities, such shortterm training courses may be a feasible approach to improving surgical care knowledge and skills. As general doctors often have compulsory rural service bonds in exchange for subsidized, government-provided medical education, the medical education should include adequate preparation for surgical care in rural settings. ${ }^{18}$ Given the Meghalaya government's documentation that only four medical officers have received training in emergency obstetric care, increasing access to training for health personnel should be prioritized and an appropriate training forum should be explored. ${ }^{6}$

Meghalaya is also included in the National Rural Health Mission (NRHM) launched by the government of India to increase availability and access to health care by the people, especially those residing in rural areas. ${ }^{19}$ The objectives for the NRHM include optimization of health manpower through training to address the shortages in rural facilities, particularly strengthening $\mathrm{CHCs}$ through establishing standards for infrastructure, staff, equipment, and to create multiskilled providers at remote posts that lack specialists. The NRHM could make substantial progress through coordination with the Department of Health and Family Welfare, government of Meghalaya. Furthermore, by working cohesively at both national and state levels to address the unmet demand for essential surgical care services, it will strengthen existing health systems. ${ }^{20}$

There are several limitations to this study. First, due to the limitations of the situation analysis tool, it cannot be used for detailed program planning. For example, the survey only accounts for certain reasons that facilities refer procedures, belying the complexity of whether "lack of skills" relates to insufficient numbers of personnel (quantity) or whether current personnel may not have sufficient training (quality). Additionally, the selection of PHCs sampled was undertaken by experts within the state Ministry of Health and, although geographically distributed, does not capture data from every first-referral facility in the state.

This article provides the first snapshot of surgical care systems throughout Meghalaya. The government of Meghalaya's support and commitment to collecting data on various facilities and identifying areas of shortage embody the core process of establishing surgical care in the national health agenda. The greatest barrier to universal surgical care is the lack of skills in current medical personnel at primary, secondary, and tertiary 
levels of care, making a coordinated emergency and essential surgical care program particularly relevant and important. As policy and initiatives are undertaken to address these identified gaps, ongoing monitoring and evaluation of progress is vital. With dedicated support from the government, improvements to surgical care systems instituted into policy can move toward creating a universal coverage reality.

\section{ACKNOWLEDGMENTS}

Dr. Mukul M Sangma, Chief Minister Meghalaya; Mr. DP Wahlang, Mission Director, National Rural Health Mission, Meghalaya; Dr. Diganata Das, Head of Anaesthesia and Critical Care, Woodland Hospital Shillong, Meghalaya; Dr. Mohd Yunus, Professor of Anaesthesia and Critical Care, NEIGRIHMS Shillong, Meghalaya; Mr. Lumbor L Mawsor, Head Oral Surgery, Shillong, Meghalaya; Mr. Daplin Marbaniang, Shillong, Meghalaya; Ms. Alia Kharkhongor (Health and Family Welfare Department, Government of Meghalaya Technical Working Group on EESC); Dr. PW Khongjee (Parliamentary Secretary Health Government of Meghalaya); Dr. AJ Ghosh, ENT Surgeon, Shillong, Meghalaya; Mr. Sunshine Marbaniang (Rajiv Gandhi Indian Institute of Management, Shillong, Meghalaya).

\section{REFERENCES}

1. Debas HT, Gosselin R, McCord C, Thind A. Surgery. In: Jamison D, editor. Disease control priorities in developing countries. 2nd ed. New York (NY): Oxford University Press; 2006. p. 1245-1259.

2. Weiser TG, Regenbogen SE, Thompson KD, Haynes AB, Lipsitz SR, Berry WR, Gawande AA. An estimation of the global volume of surgery: a modeling strategy based on available data. Lancet 2008 Jul;372(9633):139-144.

3. Penoyar T, Cohen H, Kibatala P, Magoda A, Saguti G, Noel L, Groth S, Mwakyusa DH, Cherian M. Emergency and surgery services of primary hospitals in the United Republic of Tanzania. BMJ Open 2012;2:e000369.

4. Mukerjee S, Gupta T. Surgery in India. Arch Surg 1997 Jun;132(6):571-578.

5. Government of India [Internet]. Provisional Population Totals Paper 1 of 2011: Meghalaya Census of India; 2011. Government of India Ministry of Home Affairs Office of the Registrar General and Census Commissioner, India [cited 2013 Feb 26]. Available from: http://censusindia.gov.in/2011census/ censusinfodashboard/index.html.
6. Government of Meghalaya Department of Health and Family Welfare [Internet]. Meghalaya Health [cited 2013 Mar 12]. Available from: http://meghealth.nic.in/welcome.html.

7. Rao K, Bhatnagar A, Berman P. India's health workforce: size, composition and distribution. In: La Forgia J, Rao K, editors. India health beat. New Delhi: World Bank, New Delhi and Public Health Foundation of India; 2009.

8. World Health Organization [Internet]. Emergency and essential surgical care [cited 2013 Feb 20]. Available from: http:// www.who.int/surgery/en/.

9. Mavalankar D, Siram V. Provision of anaesthesia services for emergency obstetric care through task shifting in South Asia. Reprod Health Matters 2009 May;17(33):21-31.

10. Urassa DP, Carlstedt A, Nystrom L, Massawe SN, Lindmark G. Are process indicators adequate to assess essential obstetric care at district level? A case study from Rufiji district Tanzania. Afr J Reprod Health 2005 Dec;9(3):100-111.

11. Clyburn P, Morris S, Hall J. Anaesthesia and safe motherhood. Anaesthesia 2007 Dec;67 (Suppl 1):21-25.

12. Desai S. Expanding emergency obstetric care. Delhi: Federation of Obstetric and Gynecological Societies of India and Indian College of Obstetricians and Gynecologists; 2006.

13. Evans CL, Maine D, McCloskey L, Feeley FG, Sanghvi H. Where there is no obstetrician - increasing capacity for emergency obstetric care in rural India: an evaluation of a pilot program to train general doctors. Int J Gynaecol Obstet 2009 Dec;107(3):277-282.

14. Singh A, Mavalankar DV, Bhat R, Desai A, Patel SR, Singh PV, Singh N. Providing skilled birth attendants and emergency obstetric care to the poor through partnership with private sector obstetricians in Gujarat, India. Bull World Health Organ 2009 Dec;87(12):960-964.

15. Government of Meghalaya, Directorate of Tourism [Internet]. Meghalaya at a Glance [cited 2013 Feb 20]. Available from: http://megtourism.gov.in/aboutmeghalaya.html.

16. Chu K, Rosseel P, Gielis P, Ford N. Surgical task shifting in Sub-Saharan Africa. PLoS Med 2009 May 19;6(5):e1000078.

17. Tchorz KM, Thomas N, JesudassanS, Kumar R, Chinnadurai R, Thomas A, Tchorz RI, Chaturvedula PM, Parks JK, Naylor RA. Teaching trauma care in India: an educational pilot study from Banglore. J Surg Res 2007 Oct;142(2):373-377.

18. Rao M, Rao KD, Kumar AK, Chatterjee M, Sundararaman T. Human resources for health in India. Lancet 2011 Feb 12; 377(9765):587-598.

19. Government of India, Ministry of Health and Family Welfare [Internet]. National Rural Health Mission: Ministry of Health and Family Welfare Government of India [cited 2013 Feb 20]. Available from: http://mohfw.nic.in/NRHM.htm.

20. PLoS Medicine Editors. A crucial role for surgery in reaching the UN millennium development goals. Plos Med 2008 Aug 26;5(8):e182. 